INTERNATIONAL JOURNAL OF MULTidisciplinARy RESEARCH AND ANALYSis

ISSN(print): 2643-9840, ISSN(online): 2643-9875

Volume 04 Issue 03 March 2021

DOI: 10.47191/ijmra/v4-i3-16, Impact Factor: 6.072

Page No.- 326-328

\title{
Preparation of Village Budgets as the Implementation of Good Governance of Village Government
}

\section{Wayan Sugiartana}

Study Program of Business Administration, Sekolah Tinggi Ilmu Sosial dan Politik (STISPOL) Wira Bhakti Denpasar, Indonesia

ABSTRACT: The purpose of this study is to determine the implementation of Law of the Republic of Indonesia number 14 of 2008 in the preparation of village budgets to achieve good governance in the Village Government X in terms of the dimensions of village budget design, village budget study, ratification and enactment of village budgets, stipulation of budget implementation regulations village. This research is a descriptive study, with a population of 5,575 people, and a sample of 373 people was determined using the stratified random sampling method. The questionnaire was used for data collection and then analysed using descriptive analysis techniques. The research shows that the Village Government $X$ in terms of the village budget drafting is in the agreed category. Judging from the discussion of the village budget, it is in the agreed category. Judging from the approval and promulgation of the village budget, it is in the agreed category. Judging from the implementation regulations of the village budget, it is in the very agree category. So it can be concluded that the Government of Village $X$ Regency $Y$ is able to implement Law Number 14 Year 2008 in preparing the village budget properly.

KEYWORDS: good governance; village budgets; village regulation.

\section{INTRODUCTION}

The public's right to obtain information in accordance with the 1945 Constitution in article $28 \mathrm{~F}$ is an important element in creating a transparent implementation of the State. Considering that the form of democratic state life obtains information as a human right, it is necessary to make Law no. 14 of 2008 concerning Freedom of Information (Keterbukaan Informasi Publik; KIP) [1]. Good governance requires open government as one of its foundations. One of the requirements to form an open government is a transparent, open and participatory government with freedom of information [2]. By opening public access to information, this effort can create an increase in public services and become an effort to overcome acts of corruption, collusion and nepotism for the sake of creating good governance [3].

The existence of the law on public information disclosure makes state administrators or non-governmental organizations and public companies as long as they receive funds from the state budget, regional revenue budgets, foreign aid and from public fund associations are obliged to disclose information in real time [2]. The executive institution which has the task of implementing all policies and laws established by the legislative body, in this case the executive institution in question is the village government. Village government is the lowest government executor in Indonesia, where village communities are given the right to participate in the implementation of governance and information disclosure implemented by the village government is intended so that villagers know various information about the authority and implementation of government in an accountable manner.

The implementation of village government emphasizes the ideology of democracy, community involvement, equality and justice and observes regional potential. The potential for a very strategic village position requires equal attention to the implementation of regional autonomy. The success of the government in implementing village autonomy becomes a fresh air for the successful implementation of regional autonomy. Therefore, the provincial and district governments should take steps to strengthen the village. The village government is given the authority to regulate people in rural areas by being given a good governance policy or what is often called good governance implementation in order to realize government development. As is the case in other villages that have policies to manage their government, including managing finances in accordance with good governance policies [4]-[7]. In the case of village financial management concerning the preparation of the Village Budget, the community has the right to provide input orally or in writing. 


\section{Preparation of Village Budgets as the Implementation of Good Governance of Village Government}

\section{METHOD}

In this study using descriptive research, as the purpose of this type of research is to describe the object under study with the data and make general conclusions from the data [8], [9]The Government of Village $X$ is the location for conducting research based on the problems that exist in the village that researchers want to solve for good governance. Data collection was carried out by administering a questionnaire containing a set of written statements or questions to respondents regarding the dimensions of village budget design, village budget study, ratification and enactment of village budgets, and stipulation of village budget implementation regulations. The parties involved in preparing the village budget in $\mathrm{X}$ became the population in this study with a total population of 5575 people, a sample of 373 people and obtained through stratified random sampling techniques

\section{RESULT AND DISCUSSION}

From the implementation of the research that has been carried out, the following research results were obtained

Table 1. Research Result

\begin{tabular}{llll}
\hline Dimension & Score & Range & Category \\
\hline Village budget planning & 17010 & $13950.2-17231.6$ & Agree \\
\hline Village budget assessment & 35528 & $29168.6-36030.8$ & Agree \\
\hline Ratification and promulgation of village budgets & 16982 & $13950.2-17231.6$ & Agree \\
\hline Stipulation of regulations for implementing village budgets & 9347 & $9399.6-11190$ & Strongly Angree \\
\hline
\end{tabular}

Based on the table above it can be seen, in terms of the village budget design, it is in the agreed category, all parties involved in the preparation of the village budget agree that the Village Government $X$ has implemented the applicable law in the village budget preparation in terms of the village budget design which is assessed from the indicators : (1) The Village Head and / or BPD compile the village budget draft, (2) The community participates in drafting the village budget, for example through a hearing, (3) The results of the discussion with the Village Head, Village Consultative Institute (Badan Permusyawaran Desa; BPD) and the community are used to improve the design. village budget, (4) The draft village budget that has been perfected will be presented at a review meeting and determination of the village budget draft

The village budget assessment is in the Agree category, all parties involved in the preparation of the village budget agree that the Village Government $X$ has implemented the applicable law in the preparation of the village budget in terms of the village budget review, viewed from indicators: (1) Village budget documents are received before being discussed in the BPD meeting, members of the BPD and the Village Government, (2) Submission of the Village Budget from the Village Head which will be submitted to the BPD leadership with a cover letter by the Village Head. Submission of a village budget from the BPD will be submitted with a cover letter by the proposer to the BPD leadership, (3) Village budgets are assigned to the BPD secretary to be numbered if the village budget has been given to the BPD leadership, (4) Submission at the plenary meeting that the village budget has been assigned a number, then reproduced, and distributed to all members of the BPD / Commission, (5) the Village Government or proposers from BPD members explain the village budget, (6) General opinions regarding the village budget from members of the BPD and the Village Government, (7) and / or the proposer undertakes an assessment with the commission. (8) Steps towards making a decision through the presentation of the opinion of the commission.

The ratification and promulgation of the village budget is in the agreed category, all parties involved in the preparation of the village budget agree that the Penuktukan Village Government has implemented this Law in the preparation of the village budget in terms of indicators: (1) The village budget must have been perfected before the second discussion meeting is held (2) If the revised village budget has not received approval, an approach is made with parties who have not approved it, (3) The Village Head signs or ratifies the village budget that has been approved by the BPD to become the Village Revenue and Expenditure Budget (APB-Desa). 4) The village government can use last year's village budget if the village budget proposed by the Village Head and / or part of the BPD members does not get approval from the BPD.

The stipulation of the village budget implementation regulations is in the strongly agree category, all parties involved in the preparation of the village budget agree that the Village Government $X$ has implemented the Law in preparing the village budget in terms of indicators, namely (1) the Village Head has the authority to determine budget implementation policies village as outlined in the Village Head's decision, (2) Submitting to BPD regarding the decision to determine the village budget implementation policy from the Village Head.

The results showed that Village $X$ District $Y$ in terms of village budget design, village budget review, village budget approval and enactment, and the stipulation of village budget implementation regulations were in the agreed category, this 


\section{Preparation of Village Budgets as the Implementation of Good Governance of Village Government}

means that the Village Government X plays a role in realizing good governance. The role of the Village Government X in terms of preparing the village budget is very good, starting from providing relevant information to the village community, absorbing community aspirations from the hamlet level to village level deliberations for increased community participation and always involving BPD members as an extension of the community to channel The aspirations of the community are going well, this can be seen in the participation of BPD members starting from village budget planning to the formation of village budget implementation regulations and the village government $X$ is able to allocate village funds effectively and efficiently and is always supervised by BPD and the community every decision making. So it can be concluded that the three parties involved in the preparation of the village budget have functioned properly so that the Village Government $X$ is able to implement Law of the Republic of Indonesia Number 14 of 2008 in preparing the village budget

\section{REFERENCES}

1) A. Riyanto, "Pemahaman Undang-Undang Nomor 14 Tahun 2008 Tentang Keterbukaan Informasi Publik," J. Huk. Pembang., 2012.

2) N. Febriananingsih, "Keterbukaan Informasi Publik Dalam Pemerintahan Terbuka Menuju Tata Pemerintahan Yang Baik," J. Rechts Vinding Media Pembin. Huk. Nas., 2012.

3) E. N. Kristiyanto, “Urgensi Keterbukaan Informasi Dalam Penyelenggaraan Pelayanan Publik," J. Penelit. Huk. Jure, 2016.

4) H. Widjaja, Otonomi Desa Merupakan Otonomi Yang Asli, Bulat Dan Utuh. Jakarta: Rajawali Pers, 2010.

5) M. Suparmoko, Ekonomi Publik Untuk Keuangan Dan Pembangunan Daerah. Yogyakarta: Penerbit Andi, 2002.

6) I. P. F. Karyada, P. C. Ayu, And I. G. A. Mahayasa, "Disparitas Pendapatan Asli Desa (Pades) Dan Pengelolaan Keuangan Dana Desa," J. Pendidik. Ekon. Undiksha, Vol. 12, No. 2, Pp. 282-288, 2020.

7) I. P. G. Diatmika, I. W. K. E. Putra, And M. R. Irwansyah, "Resources Efficiency Based On Village-Fund For Local Economic Development," Int. J. Multidiscip. Res. Anal., Vol. 04, No. 01, Pp. 11-17, 2021.

8) Sugiyono, Metode Penelitian Kombinasi (Mix Methods). Bandung: Alfabeta, 2015.

9) A. M. Yusuf, Metode Penelitian: Kuantitatif, Kualitatif Dan Metode Penelitian Gabungan, 4th Ed. Jakarta: Kencana, 2017. 